\title{
Erratum to: Online determination of polycyclic aromatic hydrocarbon formation from a flame soot generator
}

\author{
Laarnie Mueller • Gert Jakobi • Juergen Orasche • Erwin Karg • \\ Martin Sklorz • Gülcin Abbaszade • Benedict Weggler • Lianpeng Jing • \\ Juergen Schnelle-Kreis • Ralf Zimmermann
}

Received: 3 March 2015 / Accepted: 3 March 2015 /Published online: 25 March 2015

(C) Springer-Verlag Berlin Heidelberg 2015

\section{Erratum to: Anal Bioanal Chem}

DOI 10.1007/s00216-015-8549-x

The publisher regrets that due to a conversion problem there were mistakes in this article.

The following equations should correctly read:

$$
\frac{\left[{ }^{13} C^{12} C_{n-1}^{2+}\right]_{H R-T O F-A M S}}{y}=[P A H]_{H R-T O F-A M S}
$$

$$
\begin{aligned}
& \frac{{ }^{12} C_{n}{ }^{2+}}{\text { TIC }}=r \\
& { }^{12} C_{n}{ }^{2+} \times 0.011 \times n=P
\end{aligned}
$$

Our sincere apologies to the authors.

Published in the topical collection Aerosols and Health with guest editor Ralf Zimmermann.

The online version of the original article can be found at http://dx.doi.org/ 10.1007/s00216-015-8549-x.

L. Mueller $\cdot$ G. Jakobi $\cdot$ J. Orasche $\cdot$ E. Karg $\cdot$ G. Abbaszade $\cdot$

B. Weggler $\cdot J$. Schnelle-Kreis $(\bowtie) \cdot$ R. Zimmermann Joint Mass Spectrometry Center, Cooperation Group Comprehensive Molecular Analytics, Helmholtz Zentrum Muenchen, Ingolstaedter Landstr. 1, 85764 Neuherberg, Germany

e-mail: juergen.schnelle@helmholtz-muenchen.de

L. Mueller $\cdot$ J. Orasche $\cdot$ M. Sklorz $\cdot$ B. Weggler $\cdot$ R. Zimmermann Joint Mass Spectrometry Centre, Chair of Analytical Chemistry, Institute of Chemistry, University of Rostock, Dr.-Lorenz-Weg 1, 18059 Rostock, Germany

L. Mueller $\cdot$ G. Jakobi $\cdot$ J. Orasche $\cdot$ E. Karg $\cdot$ B. Weggler $\cdot$

R. Zimmermann

Helmholtz Virtual Institute of Complex Molecular Systems in

Environmental Health (HICE), www.hice-vi.eu

L. Jing

Jing-Cast Ltd, Im Park 4, 3052 Zollikofen, BE, Switzerland 